\title{
ATTITUDES AND MOTIVATION OF DEAF AND HARD OF HEARING STUDENTS FOR STUDYING
}

\author{
Meliha POVLAKIĆ HADŽIEFENDIĆ \\ Center for Hearing and Speech Rehabilitation, Sarajevo, \\ Bosnia and Herzegovina
}

The aim of this paper was to determine the attitudes and motivation for reading/writing and studying of deaf and hard of hearing (DHH) students and the relation of those attitudes and motivation to success at school. The sample included $47 \mathrm{DHH}$ students, of both genders, 14 to 18 years of age. The Scale for examining interests and aspiration of students (Suzić, 2003) was used. The Scale consists of eight subscales with 20 statements/indicators of attitudes for activities: studying, sports, music, TV, entertainment, reading/ writing, love and dating, and social work. Ten statements refer to involvement in aforementioned activities and another ten refer to possibilities provided by those activities. Attitudes to reading/writing and studying were assessed and the correlation between those attitudes and the general school success was established. Data was processed by descriptive analysis, and Spearman's correlation coefficient was calculated. The result was a moderate correlation between DHH students' attitudes to reading/writing $(\rho=0.61)$ and studying $(\rho=0.55)$ and their general school success, and a moderately strong correlation between the perceived possibilities offered by these activities (reading/writing $-\rho=0.46$ and studying $-\rho=0.36$ ) and the general school success, at a significance level of $p<0.05$. According to survey results, it has been established that DHH students who understood the significance of reading, writing and studying better had more positive attitudes, were more involved in these activities, and thought they provided them with better possibilities. Furthermore,

1 E-mail: melihapovlakic@hotmail.com 
Specijalna edukacija i rehabilitacija (Beograd), Vol. 18, br. 1. 85-102, 2019.

their motivation for studying was higher, as confirmed by their higher academic achievement.

Key words: studying, reading, writing, deaf, hard of hearing, success at school

\section{INTRODUCTION}

Many authors point out that deaf and hard of hearing (DHH) students lag behind despite the efforts of parents and teachers, and therefore all personality traits of hearing impaired students need to be taken into account along with all the environmental factors.

A bad correlation between the perceptual abilities of students and the demands of spoken and written English mostly attributes to the difficulties that DHH students often face in academic achievement and adaptation (Hoemann \& Briga, 1981; see Ogundiran \& Olaosun, 2013).

Although English proficiency is a learning mechanism that has been attained unconsciously by a hearing child, it is almost always a hindrance to learning for a $\mathrm{DHH}$ child, a hindrance that must be overcome consciously as an educational process section (Moores, 2001; see Moores, 2006).

"As text is a written form of what is spoken orally, mastery of reading is more difficult for those who naturally cannot hear the sounds of language" (Parault \& Williams, 2010, p. 120).

Thus, an increased stage of challenge reading poses to DHH children could cause a downturn in reading motivation and self-efficacy beliefs. Furthermore, the downturn in self-efficacy beliefs is linked to another aspect of reading motivation, work avoidance (Baker \& Wigfield, 1999; see Parault \& Williams, 2010).

DHH pupils in classrooms are battling with reading, writing and communication according to numerous surveys in the last two decades (Long et al, 2007; Antia, Reed, \& Kreimeyer, 2005; Long \& Beil, 2005; see Khwaldeh, 2011). 
The average reading attainment of $\mathrm{DHH}$ pupils resides well below that of their age-matched hearing peers, whereas the reading of roughly a half of all deaf graduates from high school is inferior to the reading standard of a fourth-grader (Cawthon, 2004; Holt, Traxler, \& Allen, 1997; Padden \& Ramsey, 1998; see Carlson, Irons, Rusher, \& Gentry, 2009).

Since DHH children have the same intellectual possibilities as hearing children, even when they have not mastered all the features and forms of English, they still have what it takes to make a high academic achievement (Miller, 2004b; see Moores, 2006).

Poor results of DHH students are not caused by lack in their verbal capabilities but rather by lack of support from their socio-cultural environment, lack of experience and information (Furt, 1973; see Radoman, 2003).

According to Stinson and Walter (1997), apart from communication, DHH pupils' academic achievement is heavily shaped by less tangible variables, for instance learning patterns, self-efficacy, program amusement, and admission in intellectually burdensome courses (Powers, 2006; see Richardson, Marschark, Sarchet, \& Sapere, 2010).

The educational demands of DHH pupils are pointed out by Esera (2008) and Schick, Williams, and Kupermintz (2006) according to El-Zraigat (2012). They list learning environment, educational interpreters, communication, visual approach appliance, and the appliance of evidence backed practices in instruction as the main educational demands of DHH pupils.

Some authors point out that that DHH students have even larger interest for studying, practicing curriculum, adopting new contents but that there is also indifference and unconcern. Deaf persons do not have enough motivation and developed interests (Levine, 1981; see Radoman, 2003).

$\mathrm{DHH}$ persons often suffer from inadequate self-concept, inadequacy, dissatisfaction with self, low self-esteem etc. (Radoman, 1991; see Radoman, 2003). 
Considering the fact that data about poor academic achievements of deaf persons cannot be generalized and also considering that there are $\mathrm{DHH}$ persons that excel academically we can safely assume that hearing impaired students cannot be considered inferior in terms of academia then their hearing peers. We have to discover which factors influence the development of interests and aspirations for studying, learning and achieving in order to stimulate them.

The aim of this paper was to determine the attitudes and motivation of deaf and hard of hearing students for reading, writing and studying and the correlation between those factors and school success.

\section{METHODS}

\section{The sample}

The sample consisted of 47 students with hearing impairment, $30(63.8 \%)$ deaf and $17(36.2 \%)$ hard of hearing students, $24(51.1 \%)$ males and 23 (48.9\%) females, at the average age of $16 \pm 1.27$ years.

\section{Measuring instrument}

The Scale for examininginterests and aspirations of students (Suzić, 2003) was used in this research. The Cronbach's alpha coefficient (Cronbach's $\alpha=0.85$ ) showed very good reliability and internal approval of the scale for this sample. The Scale consists of eight subscales. The subscales estimate students' perception of interests and aspirations for eight different activities: studying, sports, music, TV, entertainment, reading/ writing, love and dating, and social work. Attitudes toward two subscales were estimated in this research, for the activities of reading/writing and studying. The subscales consist of 20 
statements/attitudes indicators, where ten statements relate to involvement in aforementioned activities and the other ten relate to perceived possibilities and opportunities that would be the consequence of those activities.

The respondents had 6 offered responses: $0=\mathrm{I}$ do not know, 1 = never, 2 = sometimes, partly, 3 = often, $4=$ mostly and $5=$ always. The results of the questionnaire were summed up, and the total value was acquired as statistical array for processing and interpreting the results. The results ranged from 0 to 50 points. For measuring success at school, final grades from the end of the school year were taken.

\section{Data analysis}

Data was processed in SPSS program for Windows operating system. Descriptive analysis was conducted, frequencies, percentages and basic statistical parameters calculated. Correlation between attitudes towards reading/ writing, studying and general success at school was tested with Spearman's correlation coefficient.

\section{RESULTS AND DISCUSSION}

Frequencies distribution and percentages of answers to individual statements show that deaf and hard-of-hearing students considered that they were sometimes or often included into studying activities and that studying often or always provided positive possibilities and opportunities (Table 1). 
Specijalna edukacija i rehabilitacija (Beograd), Vol. 18, br. 1. 85-102, 2019.

Table 1 - Distribution of answers to being involved in studying and possibilities it provides

\begin{tabular}{|c|c|c|c|c|c|c|}
\hline Studying & $\begin{array}{c}\text { I do not } \\
\text { now }\end{array}$ & Never & $\begin{array}{l}\text { Some- } \\
\text { times }\end{array}$ & Often & Mostly & Always \\
\hline Involvement in studying & $f(\%)$ & $f(\%)$ & $f(\%)$ & $f(\%)$ & $f(\%)$ & $f(\%)$ \\
\hline 1. I spend time studying. & $0(0.0)$ & $3(6.4)$ & $16(34,0)$ & $13(27.7)$ & $9(19.1)$ & $6(12.8)$ \\
\hline 2. I'm active at studying. & $1(2.1)$ & $4(8.5)$ & $14(29.8)$ & $11(23.4)$ & $9(19.1)$ & $8(17.0)$ \\
\hline 3. I achieve a lot in studying. & $0(0.0)$ & $6(12.8)$ & $12(25.5)$ & $12(25.5)$ & $7(14.9)$ & $10(21.3)$ \\
\hline 4. I study as often as I can. & $1(2.1)$ & $5(10.6)$ & $10(21.3)$ & $15(31.9)$ & $7(14.9)$ & 9(19.1) \\
\hline 5. I like to talk about studying. & $3(6.4)$ & $7(14.9)$ & $14(29.8)$ & $12(25.5)$ & $4(8.5)$ & $7(14.9)$ \\
\hline $\begin{array}{l}\text { 6. It's important to be good at } \\
\text { studying. }\end{array}$ & $1(2.1)$ & $2(4.3)$ & $7(14.9)$ & $12(25.5)$ & $8(17.0)$ & $17(36.2)$ \\
\hline $\begin{array}{l}\text { 7. I appreciate people good at } \\
\text { studying. }\end{array}$ & $2(4.3)$ & $0(0.0)$ & $7(14.9)$ & $16(34.0)$ & $7(14.9)$ & 15(31.9) \\
\hline 8. I am satisfied when I study. & $2(4.3)$ & $5(10.6)$ & $13(27.7)$ & $9(19.1)$ & 7(14.9) & $11(23.4)$ \\
\hline 9. I wish I had more time to study & $3(6.4)$ & $5(10.6)$ & $11(23.4)$ & $12(25.5)$ & $6(12.8)$ & $10(21.3)$ \\
\hline $\begin{array}{l}\text { 10. I'm happy when I do something } \\
\text { related to studying. }\end{array}$ & $2(4.3)$ & $6(12.8)$ & 14(29.8) & $10(21.3)$ & $8(17.0)$ & $7(14.9)$ \\
\hline Studying provides possibilities & $f(\%)$ & $f(\%)$ & $f(\%)$ & $f(\%)$ & $f(\%)$ & $f(\%)$ \\
\hline 11. To show my capabilities & $0(0.0)$ & $2(4.3)$ & $8(17.0)$ & $16(34.0)$ & $6(12.8)$ & 15(31.9) \\
\hline 12. To progress & $0(0.0)$ & $3(6.4)$ & $8(17.0)$ & $14(29.8)$ & $8(17.0)$ & $14(29.8)$ \\
\hline 13. To act independently & $0(0.0)$ & $3(6.4)$ & $7(14.9)$ & $14(29.8)$ & $10(21.3)$ & 13(27.7) \\
\hline $\begin{array}{l}\text { 14. To achieve high standard of } \\
\text { living }\end{array}$ & $0(0.0)$ & $3(6.4)$ & $6(12.8)$ & $17(36.2)$ & $7(14.9)$ & 14(29.8) \\
\hline 15. To live my own way & $1(2.1)$ & $4(8.5)$ & $6(12.8)$ & $18(38.3)$ & $6(12.8)$ & $12(25.5)$ \\
\hline 16. To develop my personality & $3(6.4)$ & $3(6.4)$ & $6(12.8)$ & 15(31.9) & $8(17.0)$ & $12(25.5)$ \\
\hline 17. To be physically active & $2(4.3)$ & $7(14.9)$ & $14(29.8)$ & $10(21.3)$ & $6(12.8)$ & $8(17.0)$ \\
\hline 18. To be respected and admired & $1(2.1)$ & $2(4.3)$ & $7(14.9)$ & 15(31.9) & $6(12.8)$ & $16(34.0)$ \\
\hline 19. To be together with others & $0(0.0)$ & $7(14.9)$ & $8(17.0)$ & $14(29.8)$ & $7(14.9)$ & 11(23.4) \\
\hline $\begin{array}{l}\text { 20. To be equally involved in } \\
\text { decision making }\end{array}$ & $0(0.0)$ & $3(6.4)$ & $6(12.8)$ & $14(29.8)$ & $9(19.1)$ & 15(31.9) \\
\hline
\end{tabular}

Frequencies distribution and percentages of answers to individual statements show that DHH students most often thought that they were never involved in reading/writing activities (around 45\% for each statement) and similar answers can be found to questions about possibilities that reading/ writing activities provide, which is very concerning (Table 2). 
Povlakić Hadžiefendić, M.: Attitudes and motivation of deaf and hard of hearing students for studying

Table 2 - Distribution of answers to questions about being involved in reading/writing activities and possibilities they provide

\begin{tabular}{|c|c|c|c|c|c|c|}
\hline Reading/Writing & $\begin{array}{c}\text { I do not } \\
\text { now }\end{array}$ & Never & $\begin{array}{c}\text { Some- } \\
\text { times }\end{array}$ & Often & Mostly & Always \\
\hline Involvement in Reading/Writing & $f(\%)$ & $f(\%)$ & $f(\%)$ & $f(\%)$ & $f(\%)$ & $f(\%)$ \\
\hline 1. I spend time reading/writing & $2(4.3)$ & $21(44.7)$ & $8(17.0)$ & $8(17.0)$ & $2(4.3)$ & $6(12.8)$ \\
\hline 2. I am active in reading/writing & $1(2.1)$ & $21(44.7)$ & 9(19.1) & $8(17.0)$ & $2(4.3)$ & $6(12.8)$ \\
\hline $\begin{array}{l}\text { 3. I achieve a lot through reading/ } \\
\text { writing }\end{array}$ & $1(2.1)$ & 23(48.9) & $8(17.0)$ & $5(10.6)$ & $2(4.3)$ & $8(17.0)$ \\
\hline 4. I read/write as often as I can & $1(2.1)$ & $22(46.8)$ & $6(12.8)$ & $9(19.1)$ & $3(6.4)$ & $6(12.8)$ \\
\hline 5. I like to talk about reading/writing & 2(4.3) & $20(42.6)$ & $8(17.0)$ & $10(21.3)$ & $1(2.1)$ & $6(12.8)$ \\
\hline $\begin{array}{l}\text { 6. It is important to be good at } \\
\text { reading/writing }\end{array}$ & 2(4.3) & $20(42.6)$ & $8(17.0)$ & $10(21.3)$ & $0(0.0)$ & $7(14.9)$ \\
\hline $\begin{array}{l}\text { 7. I admire people who are good at } \\
\text { reading/writing }\end{array}$ & $0(0.0)$ & $21(44.7)$ & $5(10.6)$ & $11(23.4)$ & $2(4.3)$ & $8(17.0)$ \\
\hline 8. I am satisfied when I read/write & $1(2.1)$ & $20(42.6)$ & $9(19.1)$ & $8(17.0)$ & $2(4.3)$ & $7(14.9)$ \\
\hline $\begin{array}{l}\text { 9. I wish I had more time for reading/ } \\
\text { writing }\end{array}$ & $2(4.3)$ & $22(46.8)$ & $6(12.8)$ & $9(19.1)$ & $1(2.1)$ & $7(14.9)$ \\
\hline $\begin{array}{l}\text { 10. I am happy when I do something } \\
\text { that relates to reading/writing }\end{array}$ & $3(6.4)$ & $20(42.6)$ & $6(12.8)$ & $9(19.1)$ & $2(4.3)$ & $7(14.9)$ \\
\hline $\begin{array}{l}\text { Reading/Writing provides } \\
\text { possibilities }\end{array}$ & $f(\%)$ & $f(\%)$ & $f(\%)$ & $f(\%)$ & $f(\%)$ & $f(\%)$ \\
\hline 11. To show my capabilities & $1(2.1)$ & $20(42.6)$ & $6(12.8)$ & $8(17.0)$ & $4(8.5)$ & $7(14.9)$ \\
\hline 12. To progress & $1(2.1)$ & $22(46.8)$ & $6(12.8)$ & $8(17.0)$ & $2(4.3)$ & $8(17.0)$ \\
\hline 13. To act independently & $1(2.1)$ & $21(44.7)$ & $6(12.8)$ & $5(10.6)$ & $7(14.9)$ & $7(14.9)$ \\
\hline 14. To achieve high standar & $2(4.3)$ & $21(44.7)$ & $4(8.5)$ & $11(23.4)$ & $3(6.4)$ & $6(12.8)$ \\
\hline 15. To live my own way & 2(4.3) & $21(44.7)$ & $5(10.6)$ & $7(14.9)$ & $3(6.4)$ & $9(19.1)$ \\
\hline 16. To develop my personality & $1(2.1)$ & $21(44.7)$ & $7(14.9)$ & $6(12.8)$ & $6(12.8)$ & $6(12.8)$ \\
\hline 17. To be physically active & $1(2.1)$ & 23(48.9) & $8(17.0)$ & $6(12.8)$ & $3(6.4)$ & $6(12.8)$ \\
\hline 18. To be respected and admired & $1(2.1)$ & $20(42.6)$ & $5(10.6)$ & $9(19.1)$ & $3(6.4)$ & $9(19.1)$ \\
\hline 19. To be together with others & 3(6.4) & 19(40.4) & $5(10.6)$ & $8(17.0)$ & $4(8.5)$ & $8(17.0)$ \\
\hline $\begin{array}{l}\text { 20. To be equally involved in decision } \\
\text { making }\end{array}$ & $1(2.1)$ & 19(40.4) & $8(17.0)$ & $6(12.8)$ & $3(6.4)$ & $10(21.3)$ \\
\hline
\end{tabular}

In Table 3, basic statistical parameters of summed data for the examined variable are shown. It can be observed that average number of points that represent attitudes of $\mathrm{DHH}$ students towards involvement in studying (30.53) and reading/ writing (21.81) are lower than points that relate to possibilities that are provided by studying (33.45) and reading/writing (22.76). This indicates that $\mathrm{DHH}$ students thought that they were less involved in these activities compared to what these 
activities actually had to offer them in terms of possibilities and opportunities. In other words, although they were involved in intensive and long term rehabilitation and educational programs from the time their impairment was discovered, they believed that the involvement was not enough.

Better attitudes towards possibilities can be a baseline towards developing interests and aspirations for reading/ writing and studying. The average grade of general success at school was 4.15 out of 5 .

Table 3 - Basic statistical parameters

\begin{tabular}{lccccc}
\hline Variables & MIN & MAX & \multirow{2}{*}{ SUM } & \multirow{2}{*}{ M } & \multirow{2}{*}{ SD } \\
\hline Studying - Involvement & 10.00 & 50.00 & 1435.00 & 30.53 & 11.44 \\
\hline Studying - Possibilities & 11.00 & 50.00 & 1572.00 & 33.45 & 10.76 \\
\hline Reading/Writing - Involvement & 3.00 & 50.00 & 1025.00 & 21.81 & 13.95 \\
\hline Reading/Writing - Possibilities & 0.00 & 50.00 & 1047.00 & 22.76 & 13.63 \\
\hline Success at school & 2.00 & 5.00 & 195 & 4.15 & 0.89 \\
\hline
\end{tabular}

Spearman's correlation coefficient shows a moderate correlation between students' attitudes towards participating in reading/writing activities $(\rho=0.61)$ and studying $(\rho=0.55)$, and a moderately strong correlation between estimations of possibilities that these activities provide (reading/writing$\rho=0.46$ and studying $-\rho=0.36$ ) with general success achieved on the level of statistical significance of $\mathrm{p}<0.05$ (Table 4 ).

Positive correlation between students' attitudes with success in studying points to the fact that it is needed to involve them additionally into these activities because they think that these activities provide them with better possibilities and opportunities and therefore they can be more motivated. 
Table 4 - Results of Spearman's correlation coefficient

\begin{tabular}{|c|c|c|}
\hline Variables & & ool success \\
\hline \multirow{3}{*}{ Studying - Involvement } & $\rho$ & 0.55 \\
\hline & $p$ & 0.00 \\
\hline & $\mathrm{N}$ & 47 \\
\hline \multirow{3}{*}{ Studying - Possibilities } & $\rho$ & 0.36 \\
\hline & $p$ & 0.01 \\
\hline & $\mathrm{N}$ & 47 \\
\hline \multirow{3}{*}{ Reading/Writing - Involvement } & $\rho$ & 0.61 \\
\hline & $p$ & 0.00 \\
\hline & $\mathrm{N}$ & 47 \\
\hline \multirow{3}{*}{ Reading/Writing - Possibilities } & $\rho$ & 0.46 \\
\hline & $p$ & 0.00 \\
\hline & $\mathrm{N}$ & 47 \\
\hline
\end{tabular}

Student involvement in the educational process can be an indicator of student's interest in teaching content and school content. Both short-term and long-term influences that engagement has on pupils have been shown by numerous researches and surveys. Short term is predictive of pupils learning, grades, and manner at school (Connell, Spencer, \& Aber, 1994; Hill \& Werner, 2006; Marks, 2000; Skinner \& Belmont, 1993; Voelkl, 1997; see Lam, Wong, Yang, \& Liu, 2012).

Long term is associated to an array of life outcomes, like academic achievement, self-esteem, and socially suitable demeanor (Finn \& Rock, 1997; Hawkins, Gou, Hill, BattinPearson, \& Abbott, 2001; Maddox \& Prinz, 2003; see Lam et al., 2012).

The recognition of schoolwork significance can lead to engagement, better classroom exertion and greater learning endurance of pupils, according to empirical studies and theories (Eccles, 2008; Pintrich \& De Groot, 1990; see Voelkl, 2012).

The results of our research indicate that for $\mathrm{DHH}$ students, besides the fact that they are involved in intensive and long-lasting rehabilitation-education programs and speech and language development processes, inclusion is not enough. 
An assessment of the inadequate involvement of $\mathrm{DHH}$ students, a very important area for their development and progress, as well as an assessment of the greater ability to engage in learning, suggests that, in addition to the existing adequate and specific ways of working with this population, much more attention should be paid to the development and strengthening of motivation for learning.

Commitment is conceptualized as a flexible state of mind that is strongly influenced by the capacity of school, family, and peers to provide persistent expectations and learning approval rather than an aspect of the pupil (Reschly \& Christenson, 2006a, 2006b; see Christenson, Reschly \& Wylie, 2012).

The study revealed a variation in the extent to which deaf students use scientific principles for reasoning about science phenomena. Additionally, deaf children had a limited ability to connect the school science framework for reasoning to their daily experiences. Molander et al. generated questions about the need to consider the specific instructional approaches that would bridge the gap between a deaf learner's interaction with curriculum objectives and his or her daily experiences (Molander et al., 2001; see Namukoa, 2012).

National Technical Institute for the Deaf (NTID) pupils revealed fixating more on doing just what was crucial to "get by", but Rochester Institute of Technology (RIT) pupils were more devoted in their programs and worried about holding on with their tasks (Richardson et al., 2010).

Results that show lack of involvement of students with $\mathrm{DHH}$ were obtained through research in which students that attended separated and joint programs for children with $\mathrm{DHH}$ were compared and differences in involvement in activities of studying and learning were observed.

"The central question, in any case, is whether we can provide students with materials or instruction that builds on their cognitive and academic strengths while accommodating related needs regardless of, but appropriate to the classroom 
in which they are enrolled" (Borgna, Convertino, Marschark, Morrison, \& Rizzolo, 2011, p. 96).

According to Marschark (2005, p.1), "there are real, qualitative and quantitative differences between deaf and hearing children that can influence learning, both positively and negatively. Such differences need to be identified and utilized in developing teaching techniques appropriate for children who are deaf or hard of hearing. Ignoring such differences helps no one".

Reasons for poor academic achievements of $\mathrm{DHH}$ students can be due to the lack of interest for curriculum that is caused by the lack of understanding it. Teachers have a big role in developing students' interest. Teachers should spark interests in students by their way of conveying knowledge which should be adequately presented to a student, and in that process the student should be an active participant and not just a passive listener.

According to the results of our survey, DHH students most frequently stated that they were never involved in reading/writing activities, and their statements were similar with regard to the opportunities offered by these activities, which is alarming to all participants in the educational process with this population.

"For deaf children and adults, literacy is a vital means of accessing and learning about the larger hearing world around them. The ability to read and write is necessary in order to properly utilize newspapers, books, magazines, and other printed materials" (Grushkin, 1998, p. 181).

It is common that, in their reading achievement, hearing impaired learners lag several years behind hearing learners (e.g., Allen, 1986; Traxler, 2000; see Powers, 2003).

Reading has been recognized as a field of distinct interest and concern among scientists and educators of DHH pupils of all ages, through study addressing links of metacognition and learning in this population (e.g., Krinsky, 1990; Strassman, 1997; Walker, Munro, \& Rickards, 1998). Despite the fact that 
some DHH pupils read equally well as their hearing peers, most of them lag behind in reading sub domains of vocabulary, syntax, inferencing, and apprehension more commonly (Brown \& Brewer, 1996; Traxler, 2000; Trezek, Wang, \& Paul, 2011; see Borgna, et al., 2011).

DHH students' reading skills (and the lack thereof) have long been a preoccupation for educators and scientists. However, the challenges of vocabulary, grammar, inferencing, and relational processing inspected midst reading are also present in DHH pupils processing of signed and spoken language (depending on individual adjustment), as shown in recent researches. Such conclusions suggest that stated reading challenges are not really about reading and that they are one reason science has made such poor advancement in improving DHH pupils' reading over the past five decades (Marschark, 2009; see Borgna, et al., 2011).

Toscano et al. (2002; see Jacobs, 2010) used a sample of 30 RIT/NTID pupils who were deaf and who exhibited excellent writing and reading skills, to try to single out the components and factors linked to academic achievement. This study reported that the examinees had received great assistance and tutoring from teachers and family, and they suppose that the improvement of their reading and writing skills was done thanks to watching captioned media and adopting textbased telecommunications. Many of the examinees revealed sympathy for reading and writing from a young age which is a significant conclusion.

Attitudes of students with less involvement in learning than learning opportunities and less reading /writing involvement compared to reading/ writing opportunities (Table 3) is an indicator that all subjects in the educational process of DHH students should treat reading as a prerequisite for acquiring knowledge and need to pay much more attention to it because knowing the student's interest in reading can be a sign of motivation for learning as well as point to the quality of the teaching process. 
The task of all participants in the education process, especially teachers, but also parents, is to create optimal conditions for engagement of students in activities, which will lead to raising and exploiting opportunities and achievement of set goals, and thus greater academic achievements.

$\mathrm{DHH}$ pupils are relatively passive readers and problem solvers according to numerous researches and studies, rather than actively involved in metacognitively influenced strategies, unless guided by the teacher; and teachers mostly foster such instrumental dependence in their DHH pupils (Marschark et al., 2002; see Borgna, et al., 2011).

Instruction needs to be improved consciously and there needs to be a teacher's constant self-assessment of his or her capability as well as an assessment of the pupils themselves. We are devoted to the hypothesis that deaf children can achieve excellence, and we believe that the efforts and the help of parents, teachers, and other professionals dedicated to the learning of deaf children can lead to the aforementioned (Bloom, Walberg \& Shanahan; see Moores \& Martin, 2006).

The statistically significant correlation between the attitudes of DHH students on participation in reading-writing and learning activities, and the correlation of the assessment of the opportunities provided by these activities, obtained through our research, shows that DHH students who recognize the importance of reading, writing and learning have more positive attitudes, are involved in these activities, and consider that they provide greater opportunities to them, which is confirmed by their better school achievement.

"In spite of the absence of research on instructional models for teaching reading to deaf readers and the limited research assessing the effectiveness of instructional strategies with this population, classroom instruction clearly cannot wait for the establishment of evidence-based models and strategies" (Schirmer \& Schaffer, 2010, p. 378).

"The recognition and accommodation of their individual differences in no way demeans or undervalues the skills and 
potential of DHH students. Rather, they acknowledge the reality of growing up deaf and put educators and investigators on notice that we need to do more to understand the foundations of their learning in order to support their needs and build on their strengths" (Borgna et al., 2011, p. 97).

If involvement in certain activities is perceived by $\mathrm{DHH}$ students as personal pleasure, in the sense of progressing, independent action, achieving high standard of living, possibility to act in one's own way, they will develop higher interest and it will result in even more students joining them. It is up to, not only teachers but parents as well, to form optimal conditions for students to be involved in activities which will result in using the possibilities and opportunities which will in turn result in better academic achievements.

\section{CONCLUSION}

Based on the results of this research, it can be seen that DHH students estimate that their involvement in learning and reading/writing is less than the opportunities offered by said activities, suggesting that they are aware of the importance of learning, reading/writing, and that development and strengthening of motivation for learning is essential. This is confirmed by the statistically significant correlation between students' attitudes about participation in these activities and the opportunities they provide with overall success/achievement, where it is recognized that better students are more engaged, and are therefore more successful. The assessment of students that the research areas provide greater opportunities than their involvement in them can be found in the students themselves, the teaching process and teaching content, or in the teachers as the leaders of the educational process.

Stances of DHH students towards lack of involvement in educational process that were acquired through this research, shows that there cannot be any prejudice towards their capabilities and that teachers and other students should not 
worry about overloading them. Students have shown that they do have interests and aspirations for better academic results. Therefore, approaches and methods are very important and should be changed often with high level of creativity in order to develop, maintain and increase their interest in involvement in educational process. The level of hearing capabilities can significantly affect involvement in certain activities inside educational process and therefore the role of teachers and families is essential for students' involvement so that they can have the best opportunities and possibilities for academic achievements and general development. Where that is not the case, DHH students simply resign themselves to the fact that they are not requested to do enough, resulting in a low level of academic achievements and consequently low level of general development.

\section{REFERENCES}

1. Borgna, G., Convertino, C., Marschark, M., Morrison, C., \& Rizzolo, K. (2011). Enhancing Deaf Students' Learning from Sign Language and Text: Metacognition, Modality, and the Effectiveness of Content Scaffolding. Journal of Deaf Studies and Deaf Education, 16(1), 79-100. doi:10.1093/deafed/enq036

2. Carlson, N. L., Irons, E. J., Rusher, M. M., \& Gentry, M. A. (2009). Deaf Education: Delivered the Friendly Way. National Social Science Association. Retrieved from http://www.nssa.us/ journals/2009-31-2/2009-31-2-06.htm.

3. Christenson, S. L., Reschly, A. L., \& Wylie, C. (Eds.). (2012). Handbook of research on student engagement. New York: Springer Science \& Business Media.

4. El-Zraigat, I. A. (2012). Assessing Special Needs of Students with Hearing Impairment in Jordan and Its Relation to Some Variables. International Education Studies, 6(2), 63-75. doi:10.5539/ies.v6n2p63

5. Grushkin, D. A. (1998). Why Shouldn't Sam Read? Toward a New Paradigm for Literacy and the Deaf. Journal of Deaf Studies and Deaf Education, 3(3), 179-201. doi:10.1093/oxfordjournals.deafed.a014350 
Specijalna edukacija i rehabilitacija (Beograd), Vol. 18, br. 1. 85-102, 2019.

6. Jacobs, P. (2010). Psychosocial potential maximisation: A framework of proactive psychosocial attributes and tactics used by individuals who are deaf. Volta Review, 110(1), 5-29.

7. Khwaldeh, S. M. (2011). Implementation, use and analysis of open source learning management system "Moodle" and e-learning for the deaf in Jordan. University ofCentral Lancashire. Doctoral dissertation, Retrieved from http://clok.uclan.ac.uk/5313/2/Khwaldeh\%20 Sufian\%20Final\%20e-Thesis\%20\%28Master\%20Copy\%29.pdf.

8. Lam, S. F., Wong, B. P., Yang, H., \& Liu, Y. (2012). Understanding student engagement with a contextual model. In Christenson, S. L., Reschly, A. L., \& Wylie, C. (Eds). Handbook of research on student engagement (pp. 403-419). Boston, MA: Springer

9. Marschark, M. (2005). Looking beyond the obvious: Assessing and Understanding Deaf Learners. Retrieved from http://www.acfos. org/publication/ourarticles/pdf/acfos3/marschark.pdf.

10. Marschark, M., Convertino, C., \& LaRock, D. (2006). Optimizing academic performance of deaf students: Access, opportunities, and outcomes. In Moores, F.D. \& Martin S.D. (Eds.). Deaflearners: New developments in curriculum and instruction (pp. 179-200). Washington, D.C. 20002: Gallaudet University Press

11. Moores, F. D. (2006). Print Literacy: The Acquisition of Reading and Writing Skills. In Moores, F.D. \& Martin S.D. (Eds.). Deaf Learners. Developments in Curriculum and Instruction (pp. 4155). Washington, D.C. 20002: Gallaudet University Press

12. Moores, F. D, \& Martin, S. D. (2006). Overview: Curriculum and Instruction 3 in General Education and in Education of Deaf Learners. In Moores, F. D. \& Martin S. D. (Eds.). Deaf Learners. Developments in Curriculum and Instruction (pp. 3-15). Washington, D.C. 20002: Gallaudet University Press

13. Namukoa, A. (2012). Instruction in a Primary Language: A strategy for Teaching Children who are Deaf. African Symposium: An Online Journal of the African Education Research Network, 12(2), 51-58. Retrieved from https://pdfs.semanticscholar. org/3513/eb9a4b94ae4fa976712f00ab49fe0392f2a2.pdf.

14. Ogundiran, O., \& Olaosun, O. A. (2013). Comparison of Academic Achievement between Students with Congenital and Acquired Deafness in a Nigerian College. Journal of Education and Practice, 
4(23), 42-47. Retrieved from https://www.iiste.org/Journals/index. php/JEP/article/viewFile/8387/8688.

15. Parault, S. J., \& Williams, H. M. (2010). Reading Motivation, Reading Amount, and Text Comprehension in Deaf and Hearing Adults. Journal of Deaf Studies and Deaf Education, 15(2), 120135. doi:10.1093/deafed/

16. Powers, S. (2003). Influences of Student and Family Factors on Academic Outcomes of Mainstream Secondary School Deaf Students. Journal of Deaf Studies and Deaf Education, 8(1), 57-78. doi:10.1093/deafed/8.1.57

17. Radoman, V. (2003). Psihologija jezika i jezičkih poremećaja. Beograd: Defektološki fakultet.

18. Richardson, J. T. E., Marschark, M., Sarchet, T., \& Sapere, P. (2010). Deaf and Hard-of-Hearing Students' Experiences in Mainstream and Separate Postsecondary Education. Journal of Deaf Studies and Deaf Education, 15(4), 358-382. doi:10.1093/deafed/enq030

19. Suzić, N. (2003). Vaspitni rad u odjeljenskoj zajednici (drugo, dopunjeno izdanje). Banja Luka: Teacher Training Centre.

20. Voelkl, K. E. (2012). School identification. In Christenson, S. L. Reschly, A. L. \& Wylie, C. (Eds.). Handbook of research on student engagement (pp. 193-218). Boston, MA: Springer

21. Schirmer, B. R., \& Schaffer, L. (2010). Implementation of the Guided Reading Approach With Elementary School Deaf Students. American Annals of the Deaf, 155(3), 377-385. doi:10.1353/aad.2010.0017 


\title{
STAVOVI I MOTIVACIJA GLUVIH I NAGLUVIH UČENIKA ZA UČENJE
}

\author{
Meliha Povlakić Hadžiefendić \\ Centar za slušnu i govornu rehabilitaciju Sarajevo \\ Bosna i Hercegovina
}

\begin{abstract}
Sažetak
Cilj rada bio je utvrditi stavove i motivaciju gluvih i nagluvih učenika za čitanje, pisanje i učenje, i njihovu povezanost sa školskim uspehom. Uzorak ispitanika činilo je 47 gluvih i nagluvih učenika, oba pola, uzrasta od 14 do 18 godina. Primenjena je Skala za ispitivanje interesa i aspiracija učenika (Suzić, 2003). Skala se sastoji od osam subskala s 20 tvrdnji/indikatora stavova za aktivnosti: učenje, sport, muzika, TV, zabava, čitanje/pisanje, ljubav-izlasci i društveno koristan rad. Deset tvrdnji se odnosi na uključenost u navedene aktivnosti, a drugih deset na mogućnosti koje pružaju te aktivnosti. Procenjivani su stavovi prema čitanju/pisanju i učenju, te utvrđena povezanost stavova sa opštim školskim uspehom. Podaci su obrađeni deskriptivnom analizom i izračunat je Spearmanov koeficijent korelacije. Dobijena je umerena povezanost stavova gluvih i nagluvih učenika prema čitanju/ pisanju $(\rho=0,61)$ i učenju $(\rho=0,55)$, a srednje jaka povezanost ocene mogućnosti koje pružaju ove aktivnosti (čitanje/pisanje - $\rho=0,46$ i učenje - $\rho=0,36)$ s postignutim opštim školskim uspehom, na nivou statističke značajnosti $p<0,05$. Prema odgovorima ispitanika utvrđeno je da gluvi i nagluvi učenici koji bolje uviđaju važnost čitanja, pisanja i učenja imaju pozitivnije stavove, uključuju se u ove aktivnosti, smatraju da im one pružaju veće mogućnosti i veća je motivacija za učenje, što potvrđuju njihova bolja školska postignuća.

Ključne reči: učenje, čitanje, pisanje, gluvi i nagluvi, školski uspeh
\end{abstract} Primljeno: 11.10.2018.

Prihvaćeno: 22.02.2019. 